\title{
Perubahan Kurikulum Pendidikan Sejarah Di SMA
}

(1994-2013)

\author{
Edy Suparjan \\ STKIP Taman Siswa Bima \\ tanmaedysu@gmail.com
}

\begin{abstract}
Abstrak. Kurikulum adalah seperangkat materi pembelajaran yang diberikan kepada peserta didik dengan metode serta tehnik tertentu dengan tujuan mencapai cita-cita pendidikan nasional. Perubahan Kurikulum merupakan sesuatu hal yang sangat penting dalam sistem pendidikan nasional Indonesia, hal ini untuk menjawab kebutuhan masyarakat serta menyesuaikan perubahan sosial politik dan ekonomi dalam masyarakat. Dalam penelitian ini perumusan masalah yang dibahas adalah : Bagaimana Kedudukan Pendidikan Sejarah dalam Kurikulum Sekolah Menengah Atas (SMA). Penelitian ini bertujuan mengetahui, menganalisis dan memahami perubahan kedudukan, struktur dan isi pendidikan sejarah dalam Kurikulum 1994, 2006 dan Kurikulum Tahun 2013. Penelitian ini menggunakan metode kualitatif deskriptif dengan studi pustaka untuk menganalisis masalah yang dibahas. Kesimpulan penelitian ini bahwa perubahan Kurikulum pendidikan sejarah telah merubah posisi struktur dan isi pelajaran sejarah. Mengabaikan pendidikan sejarah sama saja dengan menghilangkan nilai-nilai luhur tokoh bangsa serta meruntuhkan masa depan bangsa. Karena kita tidak lagi memiliki cerminan kehidupan untuk membangun bangsa ini. Pemerintah harus memperkuat pelajaran sejarah sebagai mata pelajaran wajib disetiap jenjang pendidikan. Agar cita-cita bangsa tercapai.
\end{abstract}

Kata Kunci: Kurikulum, Pendidikan Sejarah

\section{PENDAHULUAN}

Pendidikan sangat penting bagi kemajuan generasi bangsa, pendidikan juga sangat menentukan arah masa depan bangsa, baik moral, kompetensinya serta pendidikan lah yang menentukan arah perkembangan peradaban manusia.

Pergantian kepemimpinan republik adalah sebuah tradisi dalam era demokrasi. Karena suksesi kepemimpinan merupakan tradisi pergantian kepemimpinan yang telah diatur dan ditetapkan lewat Undang-undang Dasar 1945. Perbedaan kepemimpinan nasional disetiap periode ikut mewarnai perubahan suatu sistem yang akan diberlakukan sesuai kebutuhan masyarakat dan disesuaikan dengan ideologi nasional. Misalnya pada masa Orde Lama sistem pendidikan atau kurikulum diarahkan untuk mendorong semangat revolusi warga negara begitu juga dengan Orde Baru sistem pendidikan nasional disesuaikan dengan tujuan pembangunan nasional, karena pasca kepemimpinan Sukarno, Orde Baru lahir dengan slogan perubahan tatanan dalam segala aspek, tidak terkecuali aspek pendidikan, dalam hal ini Orde Baru juga terkenal dengan slogan Pancasila yang konsekuen dan anti Komunis. Karena kelahiran Orde Baru juga diawali dengan pembubaran Partai Komunis Indonesia. Kemudian pada Era Reformasi tujuan pendidikan nasional disesuaikan dengan tunutan reformasi yaitu penyesuaian kurikulum pusat dengan daerah yang kita kenal dengan KTSP.

Pendidikan sangat menentukan perjalanan sejarah suatu bangsa, seluruh instrumen yang berkaitan dengannya sangat vital, contohnya Kurikulum. Kurikulum selalu disempurnakan dalam rangka meningkat mutu pendidikan secara nasioanl serta menyesuaikan perubahan sosial masyarakat. Pentingnya mutu pendidikan adalah untuk menciptakan kehidupan yang cerdas, damai, demokratis dan mampu berdaya saing dengan bangsa lain.

Tantangan bangsa saat ini semakin tidak terelakkan lagi mulai dari persaingan global seperti MEA, AFTA, G20, Kemajuan teknologi yang semakin pesat serta globalisasi yang melahirkan segala bentuk penyimpangan sosial mempengaruhi generasi bertindak dan 
berperilaku bebas jauh dari karakter tokoh bangsa dan tujuan pendidikan nasional kita.

Dalam Kurikulum SMA mata pelajaran sejarah merupakan mata pelajaran yang sangat urgen. Perubahan kurikulum tentu membawa dampak signifikan bagi perkembangan mata pelajaran sejarah, karena terkadang jika kurikulum berubah maka muatan isi kurikulum juga berubah begitu juga dengan peleburan mata pelajaran sejarah kedalam kelompok IPS atau tidak diberikan ke Jurusan IPA. Hal ini, akan membawa dampak seperti tidak diberikannya pelajaran sejarah di Jurusan IPA, kasus tersebut ditemukan bahwa ada Calon Bintara yang tidak memahami sejarah bangsanya, karena pada Jurusan IPA ketika di SMA tidak diberikan.

Apa pentingnya mengetahui dan memahami kedudukan dan posisi kurikulum pendidikan sejarah dalam kurikulum nasional kita. Untuk itu, disini penulis mengutip pendapat Prof Hamid Hasan, bahwa ada beberapa poin sehingga posisi pendidikan sejarah menjadi sangat penting untuk dijadikan mata pelajaran yang berdiri sendiri yaitu; secara tradisional pendidikan sejarah dimaknai sebagai upaya mentransfer kemegahan bangsa di masa lampau kepada generasi muda. Dengan demikian, maka pendidikan sejarah adalah wahana pewarisan nilai-nilai luhur keunggulan bangsa. Makna Kedua, upaya memperkenalkan peserta didik terhadap disiplin ilmu sejarah. Setelah peserta didik memiliki keilmuan di bidang sejarah, secara otomatis akan memiliki kemampuan analisis, penafsiran, analisis isu dan pengambilan keputusan.

Dapatlah dimengerti bahwa pendidikan sejarah sangat urgen sebagai mata pelajaran yang berdiri sendiri. Karena pendidikan sejarah selain mewariskan nilai-nilai tokoh dan kepribadian bangsa Indonesia, juga menjadi ilmu sosial yang sangat penting menganalisis kondisi perkembangan dan kemajuan suatu bangsa sehingga akan lahir pemimpinpemimpin masa depan yang tidak gegabah dalam pengambilan keputusan yang berdampak besar bagi keberlanjutan suatu bangsa. Mengabaikan pendidikan sejarah sama saja dengan menghilangkan nilai-nilai luhur tokoh bangsa serta meruntuhkan masa depan bangsa.
Karena kita tidak lagi memiliki cerminan kehidupan untuk membangun bangsa ini.

\section{METODE PENELITIAN}

Menurut Whitney dalam Natzir, (2014 : 43) metode deskripstif adalah pencarian fakta dengan interpretasi yang tepat. Penelitian deskriptif mempelajari masalah-masalah dalam masyarakat serta tata cara yang berlaku dalam masyarakat dan situasi-situasi tertentu, termasuk tentang hubungan, kegiatan-kegiatan, sikap-sikap, pandangan-pandangan, serta proses-proses yang sedang berlangsung dan pengaruh-pengaruh dari suatu fenomena.

Penelitian ini menggunakan metode deskriptif dengan pendekatan studi dokumen. Data yang digunakan adalah data sekunder berupa telaah Kurikulum 1994, 2004, 2006 dan 2013. Menurut Sanjaya, (2013:74) dokumen dapat memverifikasi data misalnya mengenai bentuk ejaan dan judul.

\section{Tujuan penelitian}

Penelitian ini bertujuan mengetahui, menganalisis dan memahami perubahan kedudukan, struktur dan isi pendidikan sejarah dalam Kurikulum 1994, 2006 dan Kurikulum Tahun 2013. Serta dampak dari perubahan kurikulum pendidikan sejarah.

\section{KAJIAN PUSTAKA}

Menurut Departemen Kementerian Pendidikan nasional, Kurikulum adalah sepereangkat rencana dan pengaturan mengenai tujuan, isi dan bahan pelajaran serta cara yang digunakan sebagai pedoman penyelenggaraan kegiatan pembelajaran untuk mencapai tujuan pendidikan tertentu. (Undang-undang Nomor 20 Tahun 2003, Bab I Pasal 1 ayat 19).

Charters 1923 menjelaskan 7 aturan menyusun Kurikulum yaitu : pertama, harus mengidentifikasi tujuan pendidikan berdasarkan riset dan perkembangan masyarakat, kedua, mengklasifikasi tujuan utama menjadi cita-cita dan kegiatan. Ketiga, memprioritaskan tujuan dan objekif pendidikan. Keempat, memprioritaskna kelima, mengidentifikasi tujuan dan sasaran yang dicapai dalam keterbatasan pengaturan sekolah. Ketujuh, mendapatkan materi dan metode berdasarkan prinsip anak. 
Menurut Hilda Taba, "siswa di kelas harus menunjukkan apa yang telah mereka pelajari dengan cara aktif dan cara mereka sendiri. Peran guru adalah meyediakan berbagai contoh pengalaman dan pembelajaran yg memungkinakan peserta didikuntuk belajar dari guru tersebut.

Michael F.D Young mengatakan bahwa Peran Kurikulum adalah memutuskan apa yang harus dilakukan sekolah maupun hal2 yang tidak dilakukan. Young lebih menekankan Kurikulum harus menjadi praksis, yaitu harus lebih fokus menyelsaikan masalah sosial ekonomi yang bekembang di masyarakat. Rahmat Hidayat, (2011: 59). Pemikiran Young banyak dipengaruhi oleh Durkheim dan Vigotsky.

Kurikulum secara umum merupakan seperangkat rencana tertulis tentang bahan ajar dan kemampuan yang harus dimiliki berdasarkan standar nasional

$$
\text { Menurut Hasan, }
$$
pembelajaran sejarah bertujuan membentuk karakter bangsa. Jadi, kalau Kurikulum pendidikan sejarah tidak terarah dan penuh dengan muatan politis ideologi tertentu. Maka konsekuensinya adalah pembentukan karakter generasi bangsa akan sulit, apalagi kalau pemerintah sudah tidak menganggap pendidikan sejarah sebagai mata pelajaran wajib. Wacana pemerintah yang ingin menghapus pelajaran Agama dan mengurangi jam pelajaran sejarah disekolah, justru tidak memberikan solusi bagi pembentukan karakter generasi bangsa. Hal ini bagi penulis menandakan bahwa pemerintah tidak paham sejarah sama sekali.

Tujuan pendidikan sejarah di SMA adalah :

1. Mengembangkan pendalaman tentang peristiwa sejarah terpilih baik lokal maupun nasional

2. Mengembangkan kemampuan berpikir kritis dan kreatif

3. Membangun kepedulian sosial dan semangat kebangsaan

4. Mengembangkan rasa ingin tahu, inspirasi dan aspirasi

5. Mengembangkan nilai dan sikap kepahlawanan dan kepemimpinan
6. Mengembangkan

kemampuan berkomunikasi

7. Mengembangkan kemampuan mencari, mengolah, mengemas, dan mengkomunikasikan informasi.

Secara umum materi pendidikan sejarah yang diajarkan disekolah adalah materi sejarah politik; jatuh bangunnya kekuasaan, peperangan antara dua kekuasaan politik dalam memperebutkan hegemoni terhadap suatu wilayah tertentu.

\section{PEMBAHASAN}

\section{Pendidikan Sejarah Dalam Kurikulum 1994}

Kurikulum 1994 disusun dalam era pemerintahan orde baru yang sedikit banyak memberikan pengaruh dalam kerangka penyusunan materi bahan ajar bagi pserta didik, terutama untuk materi sejarah, dan pendidikan kwarganegaraan. Banyak perubahan dalam substansi maupun struktur pelaksanaan pendidikan dan pembelajaran. Menurut Layton dalam Widyastono, Kurikulum dipengaruhi oleh sistem sosial politik, ekonomi, teknologi, moral keagamaan, dan estetika.

Kondisi demikian turut mempengaruhi substansi kurikulum pendidikan yang berimbas pada penyampaian bahan ajar disekolah. Sebagai contoh pada materi ajar tentang Gerakan 30 September/ PKI, masa awal orde baru, Supersemar, dan proses integrasi Timortimor ke dalam NKRI. Materi tersebut sebelumnya dimuat pada mata pelajaran Sejarah Perjuangan Bangsa pada kurikulum tahun 1984, yang khusus membahas sejarah Indonesia, selain itu ada juga pelajaran sejarah umum, namun kemudian dihapuskan dengan tujuan politik tertentu dari pemerintah.

Kurikulum pendidikan tahun 1994 untuk SMA meupakan kurikulum pengganti yang diarahkan untuk memperbaiki kurikulum pendidikan tahun 1984. Dalam kurikulum 1984 peserta didik di minta belajar untuk mencari dan menemukan sendiri apa yang mereka ingin tahu melalui cara belajar siswa aktif (CBSA), maka dalam aplikasinya Kurikulum 1994 lebih menekankan pada pemahaman konsep dan keterampilan menyelesaikan soal dengan pemecahan masalah. 
Kurikulum 1994 adalah seperangkat rencana/peraturan yang menekankan pada cara belajar siswa aktif secara fisik, mental, intelektual dan emosional guna memperoleh hasil belajar yang berupa perpaduan antara pengetahuan, sikap dan keterampilan.

Perubahan politik pasca Orde Baru menuju Reformasi dengan perubahan yang cukup signifikan lebih khususnya desentralisasi, karena pada masa Orde Baru kurikulum masih bersifat sentralistik. Maka kehadiran Kurikulum Berbasis Kompetensi sebagai kelanjutan dari Kurikulum 1994 membawa angin segar sekaligus membawa badai kontroversi. Membawa angin segar karena kurikulum ini memberikan kewenangan daerah dalam menambah jumlah jam dan menyesuaikan kurikulum dengan kondisi serta kebutuhan daerah. Sementara membawa badai buruk menurut Suparjan, (2019 : 34) adalah ketika penghapusan kata PKI pada salah satu materi pokok sejarah. Hal ini menurut penulis bukti inkonsistensi pemerintah dalam menempatkan pendidikan sejarah sebagai pendidikan yang membentuk karakter generasi bangsa dan mencetak pemimpin masa depan.

\section{Struktur Kurikulum Tahun 1994}

Kurikulum 1994 adalah sebuah
kurikulum operasional pendidikan yang disusun dan dilaksanakan di masing-masing satuan pendidikan di Indonesia yang dipakai sejak tahun ajaran 1994/1995 hingga 2004. Kurikulum 1994 dibuat sebagai penyempurnaan kurikulum 1984 dan dilaksanakan sesuai dengan Undang-undang Nomor 2 Tahun 1989 tentang sistem Pendidikan Nasional. Dampak usaha revisi kurikulum tahun 1984 ke Kurikulum 1994 tampak pada sistem pembagian waktu pelajaran, yaitu dengan mengubah dari sistem semester ke sistem caturwulan. Dengan sistem caturwulan yang pembagiannya dalam satu tahun menjadi tiga tahap diharapkan dapat memberi kesempatan lebih luas bagi siswa untuk menerima materi pelajaran.

Secara rasional kurikulum ini menyesuaikan ketentuan Undang-undang Nomor 02 Tahun 1989 tentang sistem pendidikan Nasional (UU Tentang SPN No. 2
Tahun 1989) adalah perubahan waktu kegiatan pembelajaran dari sistem semester ke sistem Caturwulan. Dengan sistem caturwulan pembagian waktu kegiatan pembelajaran terbagi menjadi tiga periode, dengan demikian hasil belajar peserta didik (rapor) dapat lebih cepat diketahui oleh orang tua peserta didik.

Struktur Kurikulum Pendidikan Menengah Atas, penjurusan diadakan di kelas III SMA. Sedangkan kelas 1 dan 2 merupakan program umum yang diikuti oleh semua peserta didik. Penjurusan di kelas 3 diambil beberapa pertimbangan sebagai berikut. :

1. Secara empirik perguruan tinggi memilih calon mahasiswa yang memiliki penguasaan materi mata pelajaran SMA sebagai learning tools secara memadai yang dapat ditransfer untuk menempuh pendidikan yang lebih tinggi.

2. Yang termasuk learning tools adalah semata-mata pelajaran sains, matematika, dan bahasa serta mata pelajaran lain yang menanamkan cara berfikir saintifik;

3. Guna memperkuat bekal untuk memasuki perguruan tinggi, maka bilamana siswa SMA hanya diberi kesempatan 1 tahun untuk mengikuti mata pelajaran sebagaimana butir 2, tidaklah mencukupi, sehingga sebagian besar kesempatan atau peluang memasuki perguruan tinggi akan direbut oleh para siswa dari jurusan IPA atau jurusan Matematika; dan

4. Oleh karena itu, perlu diberikan kesempatan yang memadai bagi semua siswa SMA untuk memperoleh bekal sebagaimana butir 2 dalam kurun waktu 2 tahun, yaitu dikelas 1 dan kelas 2 . Dengan demikian maka penjurusan SMU diadakan dikelas 3. Jurusan dalam kurikulum 1994 disebut program. Jurusan atau program tersebut adalah jurusan program bahasa, program IPA dan program ilmu-ilmu sosial. Beberapa pertimbangan yang digunakan dalam penentuan program di SMU antara lain adalah; 1) kebutuhan perguruan tinggi dalam menyeleksi calon mahasiswa terutama periode seleksi mahasiswa sampai dengan tahun 1990-an ; 2) nampaknya seleksi masuk perguruan tinggi dalam masa tersebut butir 1 
berfokus pada 3 kelmpok penguasaan materi, yaitu; a) penguasaan materi terkait dengan bahasa dan sastra; b) penguasaan terkait dengan sains dan matematika; c) penguasaan materi terkait ilmu-ilmu sosial. Dengan catatan setiap siswa SMU sudah memperoleh bekal sains dan matematika secara memadai di kelas 1 dan kelas 2 SMU.

\section{Karakteristik Kurikulum 1994}

Kurikulum 1994 memiliki beberapa karakteristik yang cukup mengemuka sebagai pengganti kurikulum 1984, yaitu :

1. Menekankan pada ketercapaian kompetensi siswa baik secara individual maupun klasikal

2. Beroreantasi pada hasil belajar dan keberagaman

3. Penyampaian dalam pembelajaran menggunakan pendekatan metode bervariasi

4. Sumber belajar bukan hanya guru, tetapi juga sumber belajar lainnya yang memenuhi unsur edukatif

5. Penilaian menekankan pada proses dan hasil belajar dalam upaya penguasaan atau pencapaian suatu kompetensi

6. Terdapatnya tujuan, visi-misi, struktur dan muatan kurikulum, beban belajar, kalender pendidikan hingga silabusnya.

7. Pembagian tahapan pelajaran disekolah dengan sistem caturwulan.

8. Pembelajaran disekolah lebeih menekankan materi pelajaran yang cukup padat (beroreantasi pada isi)

9. Kurikulum 1994 bersifat populis, yatu yang memberlakukan satu sistem kurikulum untuk semua siswa di seluruh Indonesia. Kurikulum ini bersifat kurikulum inti sehingga daerah yang khusus dapat mengembangkan pengajaran sendiri disesuaikan dengan lingkungan.

10. Kurikulum 1994 mengembangkan sistem belajar yang disebut Cara Belajar Siswa Aktif. Dalam pelaksanaan kegiatan, guru memilih menggunakan strategi melibatkan siswa aktif dalam belajar, baik fisik maupun mental.

\section{Pendidikan Sejarah Dalam Kurikulum KTSP \\ Struktur Dan Muatan KTSP}

1. Kurikulum dan program keagamaan terdiri atas 13 Mata Pelajaran, muatan lokal

2. Jam pembelajaran untuk setiap mata pelajaran dialokasikan sebagaimana tertera dalam struktur kurikulum satuan pendidikan dimungkinkan menambah maksimum empat jam pembelajaran per minggu scara keseluruhan

3. Alokasi waktu satu jam pembelajaran adalah 45 menit

4. Minggu efektif dalam satu tahun pelajaran adalah 34-38 minggu.

Tabel. 1. Struktur Kurikulum SMA/MA Kelas

\begin{tabular}{|c|c|c|c|c|}
\hline \multicolumn{5}{|c|}{ XI dan Kelas XII } \\
\hline \multirow[t]{3}{*}{ Komponen } & \multicolumn{4}{|c|}{ ALOKASI WAKTU } \\
\hline & \multicolumn{2}{|l|}{ KELAS XI } & \multicolumn{2}{|c|}{ KELAS XII } \\
\hline & $\begin{array}{c}\text { Semester } \\
1\end{array}$ & $\begin{array}{c}\text { Semester } \\
2 \\
\end{array}$ & $\begin{array}{c}\text { Semester } \\
1 \\
\end{array}$ & $\begin{array}{c}\text { Semester } \\
2 \\
\end{array}$ \\
\hline $\begin{array}{ll}\text { A. } & \text { MATA } \\
& \text { PELAJA } \\
& \text { RAN } \\
\end{array}$ & & & & \\
\hline $\begin{array}{l}\text { Pendidikan } \\
\text { Agama }\end{array}$ & 2 & 2 & 2 & 2 \\
\hline $\begin{array}{l}\text { Pendidikan } \\
\text { Kwarganegara } \\
\text { an }\end{array}$ & 2 & 2 & 2 & 2 \\
\hline $\begin{array}{l}\text { Bahasa } \\
\text { Indonesia }\end{array}$ & 4 & 4 & 4 & 4 \\
\hline $\begin{array}{l}\text { Bahasa } \\
\text { Inggris }\end{array}$ & 4 & 4 & 4 & 4 \\
\hline Matematika & 4 & 4 & 4 & 4 \\
\hline Sejarah & 3 & 3 & 3 & 3 \\
\hline Geografi & 3 & 3 & 3 & 3 \\
\hline Ekonomi & 4 & 4 & 4 & 4 \\
\hline Sosiologi & 3 & 3 & 3 & 3 \\
\hline Sni budaya & 2 & 2 & 2 & 2 \\
\hline $\begin{array}{l}\text { Pendidikan } \\
\text { Jasmani dan } \\
\text { Olahraga }\end{array}$ & 2 & 2 & 2 & 2 \\
\hline $\begin{array}{l}\text { Teknologi } \\
\text { Informasi dan } \\
\text { Komunikasi }\end{array}$ & 2 & 2 & 2 & 2 \\
\hline $\begin{array}{l}\text { Keterampilan } \\
\text { bahasa asing }\end{array}$ & 2 & 2 & 2 & 2 \\
\hline $\begin{array}{ll}\text { B. } & \text { MUATA } \\
\mathrm{N} \\
\text { LOKAL } \\
\end{array}$ & 2 & 2 & 2 & 2 \\
\hline $\begin{array}{l}\text { PENGEMBA } \\
\text { NGAN DIRI }\end{array}$ & $2 *$ & $2 *$ & $2 *$ & $2 *$ \\
\hline
\end{tabular}

2*) Ekuivalen 2 Jam pembelajaran 


\section{Karakteristik KTSP}

1. Pemberian otonomi luas kepada sekolah dan satuan pendidikan, disertai seperangkat tanggungjawab untuk mengembangkan kurikulum sesuai dengan kondisi setempat

2. Partisipasi masyarakat dan orangtua yang tinggi ; dalam KTSP pelaksanaan kurikuulm didukung oleh partisipasi masyarakat, orangtua peserta didik yang tinggi dan masyarakat tidak hanya mendukung sekolah melalui bantuan keuangan, tetapi melalui komite sekolah dan dewan pendidikan merumuskan serta mengembangkan program-program yang dapat meningkatkan kualitas pembelajaran

3. Kepemimpinan yang demokratis dan profesional; dalam KTSP pengembangan dan pelaksanaan kurikulum ddukung oleh adaya kepemimpinan sekolah yang demokratis dan profesional. Kepala sekolah dan guru-guru sebagai tenaga pelaksana kurikulum merupakan orang yang memiliki kemampuan dan integritas.

4. Tim kerja yang kompak dan transparan; keberhasilan KTSP didukung oleh kinerja Tim yang kompak dan transparan dari berbagai pihak yang terlibat dalam pendidikan.

5. Sistem informasi yang jelas dan transparan

6. Sistem penghargaan dan hukuman.

\section{Posisi Pendidikan Sejarah Pada Kurikulum KTSP}

Pada Kurikulum 2006 posisi mata pelajaran sejarah berdiri sendiri masuk ke kelompok program pengajaran umum untuk kelas X SMA. Pada kelas XI hingga kelas XII jumlah jam mata pelajaran sejarah 2 jam per minggu. Bedanya pada tahun 1984 menggunakan sistem kredit dalam setiap semester, sedangkan tahun 1994 menggunakan sistem cawu.

Dalam struktur kurikulum 2006 jumlah jam pelajaran sejarah berbeda dengan program yang berbeda. Kelas XI IPA siswa akan memperoleh jam sejarah 1 jam per minggu, untuk program/jurusan IPS mendapat 3 jam per minggu dan program bahasa 2 jam per minggu. Pemberian jam pelajaran sejarah seperti itu telah menimbulkan reaksi terutama dari para guru sejarah, karena dengan posisi pendidikan sejarah yang dibedakan antara kelas IPA dan lainnya menandakan bahwa pendidikan sejarah tidak dianggap penting dalam kurikulum 2006.

Kompetensi Lulusan Sma/Ma Pada Mata Pelajaran Sejarah

1. Menganalisis kehidupan awal, peradaban manusia Indonesia dan bangsa-bangsa lain didunia, serta asal-usul dan persebaran manusia di Indonesia

2. Menganailisis perkembangan bangsa Indonesia pada masa negara tradisional, meliputi perkembangan budaya, agama, dan sistem pemerintahan masa hinduBdha, masa Islam, proses interaksi antara tradisi lokal, Hindu-Budha

3. Menganalisis kesejarahan masa kolonial Hindia Belanda meliputi perubahan ekonomi, demografi, sosial serta politik dan masa kolonial Jepang.

4. Menganalisis pengaruh berbagai revolusi politik dan sosial di dunia (Revolusi Prancis, Reovolusi Amerika, Revolusi Rusia) terhadap perubahan sosial ekonomi dan politik Indonesia.

5. Menganalisis peritiwa Proklamasi 17 Agustus 1945, terbentuknya negara kesatuan republik Indonesia, dan lahirnya UUD 1945.

6. Menganalisis perkembangan masyarakat Indonesia mulai masa kerajaan HinduBudha, Kerajaan-kerajaan Islam, pemerintahan kolonial Belanda, Inggris, pemerintahan pendudukan Jepang, meliputi politik, gerakan pendidikan dan nasionalisme.

7. Menganailisis perjuangan dalam mempertahankan kemerdekaan dan persatuan NKRI dari ancaman Disintegrasi bangsa, antara lain peristiwa Madiun 1948, pemberontakan DI/TII, Peristiwa Permesta, Peristiwa Andi Azis, RMS, PRRI, dan gerakan G 30 S/PKI.

8. Menganalisis perkembangan masyarakat Indonesia sejak proklamasi sampai dengan Masa Orde Baru, Reformasi, meliputi pemerintahan Demokrasi Terpimpin, (Orde Lama, 1945-1967), Masa Demokrasi Pancasila (Orde Baru, 1967- 
1998) dan masa peralihan ke reformasi 1998 sampai sekarang.

\section{A.PENDIDIKAN SEJARAH DALAM KURIKULUM 2013}

Kurikulum 2013 bertujuan untuk mempersiapkan manusia Indonesia agar memiliki kemampuan hidup sebagai pribadi dan warga negara yang beriman, produktif, kreatif inovatif, dan afektif serta mampu berkontribusi pada kehidupan bermasyarakat, berbangsa, bernegara dan peradaban dunia.

Sejarah Indonesia bertujuan untuk menyiapkan siswa memiliki nasionalisme sebagai warga bangsa yang baik, sedangkan sejarah yang menjadi bagian dari peminatan Ilimu-ilmu sosial adalah untuk menyiapkan siswa melanjutkan pendidikan yang lebih tinggi. Struktrur Kurikulum SMA/ MA

Struktur kelompok mata pelajaran wajib dalam Kurikulum SMA/MA adalah sebagai berikut :

\begin{tabular}{|c|c|c|c|c|}
\hline \multirow{2}{*}{\multicolumn{2}{|c|}{ MATA PELAJARAN }} & \multicolumn{3}{|c|}{$\begin{array}{c}\text { ALOKASI } \\
\text { WAKTU } \\
\text { PER MINGGU }\end{array}$} \\
\hline & & $\mathrm{X}$ & XI & XII \\
\hline \multicolumn{5}{|c|}{ KELOMPOK WAJIB } \\
\hline 1 & $\begin{array}{l}\text { Pendidikan } \\
\text { Agama dan } \\
\text { Budi Pekerti }\end{array}$ & 3 & 3 & 3 \\
\hline 2 & $\begin{array}{l}\text { Pendidikan } \\
\text { Pancasila } \\
\text { dan } \\
\text { kwarganega } \\
\text { raan }\end{array}$ & 2 & 2 & 2 \\
\hline 3 & $\begin{array}{l}\text { Bahasa } \\
\text { Indonesia }\end{array}$ & 4 & 4 & 4 \\
\hline 4 & Matematika & 4 & 4 & 4 \\
\hline 5 & $\begin{array}{l}\text { Sejarah } \\
\text { Indonesia }\end{array}$ & 2 & 2 & 2 \\
\hline 6 & $\begin{array}{l}\text { Bahasa } \\
\text { Inggris }\end{array}$ & 2 & 2 & 2 \\
\hline \multicolumn{5}{|c|}{$\begin{array}{l}\text { KELOMPOK } \\
\text { (WAJIB) }\end{array}$} \\
\hline 7 & Seni budaya & 2 & 2 & 2 \\
\hline 8 & $\begin{array}{l}\text { Pendidikan } \\
\text { Jasmani, } \\
\text { Olahraga } \\
\text { dan } \\
\text { kesehatan }\end{array}$ & 3 & 3 & 3 \\
\hline 9 & Prakarya & 2 & 2 & 2 \\
\hline
\end{tabular}

Jurnal Ilmu Sosial dan Pendidikan

\begin{tabular}{|l|l|l|l|}
\hline \multicolumn{1}{|c|}{$\begin{array}{l}\text { dan } \\
\text { kewirausaha } \\
\text { an }\end{array}$} & & & \\
\hline $\begin{array}{l}\text { Jumlah jam Pelajaran } \\
\text { Kelompok A dan B Per } \\
\text { minggu }\end{array}$ & 24 & 24 & 24 \\
\hline $\begin{array}{l}\text { Kelompok C } \\
\text { (Peminatan) pelajaran }\end{array}$ & 18 & 20 & 20 \\
\hline $\begin{array}{l}\text { Mata untuk } \\
\text { peminatan akademik }\end{array}$ & 24 & 44 & 44 \\
\hline $\begin{array}{l}\text { Mata } \\
\text { peminatan } \\
\text { SMK/MAK Jelajaran }\end{array}$ & 48 & 48 & 48 \\
\hline $\begin{array}{l}\text { Jumlah Jam per } \\
\text { yang harus ditempuh per } \\
\text { minggu untuk SMA/MA }\end{array}$ & & & \\
\hline $\begin{array}{l}\text { Jumlah Jam pelajaran } \\
\text { yang harus ditempuh } \\
\text { perminggu SMK/MAK }\end{array}$ & & & \\
\hline
\end{tabular}

\section{B.MUATAN PENYUSUNAN PENDIDIKAN SEJARAH \\ POLITIS DALAM KURIKULUM}

Kurikulum 2013 merupakan kurikulum yang mulai diterapkan pada tahun 2013/2014. Kurikulum ini adalah pengembangan dan penyempurnaan kurikulum sebelumnya baik KBK yang dirintis pada tahun 2004 maupun KTSP tahun 2006.

Kurikulum adalah pedoman pembelajaran di tingkat pendidikan, yang namanya pedoman tentu memerlukan penyempurnaan-penyempurnaan yang disesuaikan dengan kondisi perubahan sosial politik dan tujuan negara. Hal inilah sebagai pintu masuk intervensi politik dalam perancangan kurikulum.

Kurikulum juga bisa menjadi alat legitimasi untuk rezim yang sedang berkuasa dan menanamkan paham-paham dan konten yang sesuai dengan penguasa. Contohnya Orde Baru menanamkan pengaruhnya lewat kurikulum seperti pada Kurikulum 1968, dan kurikulum 1975 pasca kejadian G 30 S, dengan kekuasaan G 30 S Kemudian disematkan kepada PKI, sehingga jadilah G 30 S/PKI. Hal tersebut menjadikan kurikulum sebagai komoditas politik dan alat legitimasi. 
Salah satu masalah dalam pengembangan kurikulum tahun 2004, adalah hilangnya kata PKI pada salah satu komponen materi dalam mata pelajaran sejarah yaitu Gerakan 30 September 1965. Masalah ini membuat keresahan ditingkat masyarakat maupun ditingkat elit. Hal ini, cepat diatasi oleh Menteri Bambang Sudibyo, meminta kepada Kejaksaan Agung untuk turun memeriksa buku-buku sejarah yang tidak mencantumkan kata PKI.

Dalam kurikulum 2013 penjelasan tentang Materi G 30 S/PKI tidak lagi menoton PKI sebagai dalang utama pemberontakan 1965. Namun materi G 30 S telah dijelaskan dari berbagai teori dan sudut pandang, termasuk dalam hal ini keterlibatan CIA. Walau sudah dijelaskan beragam versi, penulis masih melihat masih ada sikap inkonsistensi penulis buku teks sejarah, karena masih ditemukan kata G 30 S/PKI. Hal ini akan berdampak pada kebingungan bagi para pembaca dalam menganalisis isi buku mata pelajaran sejarah kelas XII.

Mengenai tafsiran mengenai peristiwa sejarah yang kontroversi, Hasan menjelaskan dalam konteks pendidikan sejarah maka tafsiran resmi pemerintah atau official history yang harus digunakan. Yang dimaksud dengan official history adalah kebenaran sejarah bukan saja dipandang berdasarkan kajian ilmu pengetahuan semata, akan tetapi lebih pada pertimbangan kebenaran berdasarkan kaidah kepentingan bangsa.

Tentu kurikulum sangat berkaitan dengan kepentingan penguasa. Tilaar, 1995, kolonialisme Belanda memberikan pelajaran bagi kita bahwa semua kurikulum sekolah mengacu kepada kurikulum di Belanda. Pada saat itu kurikulum Belanda dioreantasikan untuk kebutuhan pembangunan sarana produksi. Bagi Tilaar juga, dibalik kurikulum selalu terjadi konstetasi kekuasaan. Konstetasi kekuasaan merupakan sebuah bentuk perjuangan dan pertarungan berbagai pihak yang berkepentingan dengan produksi kurikulum.
Maka sangatlah jelas bahwa perubahan kurikulum sarat dengan kepentingan politik baik menanamkan suatu paham atau ideologi tertentu maupun kepentingan-kepentingan kelompok tertentu. Jika kita mengacu pendapat Tilaar diatas maka sangat wajar ketika banyak penolakkan dari berbagai pihak, ketika dalam Kurikulum 2004 terjadi penghapusan kata PKI.

\section{KESIMPULAN}

Perubahan Kurikulum mulai Tahun 1994, 2004, 2006 sampai tahun 2013 sangatlah berpengaruh terhadap struktur maupun muatan isi kurikulum pendidikan sejarah. Bisa dilihat ketika penerapan Kurikulum Tahun 2004 dalam struktur Kurikulum 2004 mata pelajaran sejarah di kelas X diberikan 1 Jam di semester satu dan 2 Jam di semester 2. Kemudian di kelas XI dan XII masing-masing diberikan 2 jam pelajaran. Selain itu, isi mata pelajaran sejarah terjadi perubahan yang sangat fatal yaitu dihapuskannya kata PKI dalam uraian materinya.

Dalam struktur Kurikulum 2013 kelompok Mapel Wajib mata pelajaran sejarah di kelas X, XI, XII diberikan masing-masing 2 jam pelajaran. Kemudian dalam kelompok mapel peminatan sejarah diberikan masingmasing 3, 4 dan 4 Jam pelajaran dikelas X, XI dan XII. Kurikuluum 2013 dirancang agar lulusan tidak hanya memiliki kemampuan kompetensi pengetahuan semata, namun keterampilan untuk menjawab persaingan global. Ditengah krisis moral seperti saat ini melalui pendidikan sejarah sudah saatnya guruguru menggali makna tiap peristiwa, atau makna perilaku dan karakter tokoh sejarah yang dijadikan pedoman bagi peserta didik saat ini. Pendidikan sejarah di SMA harus menjawab krisis moral yang menerpa bangsa ini.

Mengabaikan pendidikan sejarah sama saja dengan menghilangkan nilai-nilai luhur tokoh bangsa serta meruntuhkan masa depan bangsa. Karena kita tidak lagi memiliki cerminan kehidupan untuk membangun bangsa ini. 


\section{DAFTAR PUSTAKA}

Dokumen Kurikulum 2013 Bahan Uji Materi Publik Kurikulum 2013.

Hamid Hasan. 2012 Pendidikan Sejarah Indonesia, Isu dalam Ide dan Pembelajaran. Bandung: Rizqi Press,

Rakhmat Hidayat. 2011 Pengantar Sosiologi Kurikulum. Jakarta : Rajawali Pers,

Hamalik. 2009 Manajemen Pengembangan Kurikulum. Yogyakarta: Pustaka Pelajar,

Widyastono. 2014 Pengembangan Kurikulum di Era Otonomi Daerah. Jakarta : Bumi Aksara.

Wage Wardana.2015. tinjauan dan Telaah Kurikulum 2013. Makalah dalam Kuliah Pascasarjana Pendidikan Sejarah Universitas Negeri Jakarta

Edy Suparjan. 2019. Pendidikan Sejarah untuk membentuk Karakter Bangsa. Yogyakarta : Depublish.

Undang-undang Nomor 02 Tahun 2003 Tentang Sistem Pendidikan Nasional.

Moch Natsir. 2013. Metode Penelitian. Bogor : Ghalia Indonesia. 